\title{
Building peace through the nexus between security, democracy and development: a critical assessment of the United Nations mission in Liberia
}

Construyendo la paz por medio del nexo seguridad, democracia y desarrollo: una evaluación critica de la misión de las Naciones Unidas en Liberia

Matheus de Abreu Costa Souza

Pontifical Catholic University of Rio de Janeiro matheusdeacsouza@gmail.com

Cristiano Garcia Mendes

Pontifical Catholic University of Minas Gerais cristianomendes@gmail.com

\begin{abstract}
The United Nations (UN) peacebuilding strategy often establishes a nexus between security, democracy and development. This strategy states that sustainable peace could be achieved whenever institutional reforms towards democratization and economic development take place. In this paper, we intend to identify whether the strengthening of state institutions in the aforementioned sectors contributes to tackling the root causes of intrastate warfare. Methodologically, this paper consists of a case study of the United Nations Mission in Liberia (2003-2018). To evaluate the effectiveness of the peacebuilding policies deployed in Liberia, we have gathered empirical data to identify advantages and flaws in the UN approach. Our findings show that although policies regarding the nexus between security, democracy and development have addressed some crucial post-conflict issues, reforms in these areas were unsuccessful to fragment local elites, avoid uneven economic development and ensure horizontal welfare for Liberians.
\end{abstract}

Keywords: Peacebuilding, UN Peace Operations, Peace, Security, Development, Democracy, Liberia

\section{Resumen}

La estrategia de construcción de la paz de las Naciones Unidas (ONU) generalmente establece un nexo entre seguridad, democracia y desarrollo. Por lo tanto, argumenta que se puede lograr una paz sostenible siempre que se realicen reformas institucionales hacia la democratización y el desarrollo económico. Tenemos la intención de identificar si el fortalecimiento de las instituciones estatales en los sectores antes mencionados contribuye a abordar las causas principales de la guerra intraestatal. Metodológicamente, este artículo consiste en un estudio de caso de la Misión de las Naciones Unidas en Liberia (2003-2018). Para evaluar la efectividad de las políticas de construcción de la paz implementadas en Liberia, hemos reunido datos empíricos para identificar ventajas y fallas en el enfoque de la ONU. Nuestros hallazgos evidencian que, aunque las políticas relacionadas con el nexo entre seguridad, democracia y desarrollo han abordado algunos problemas cruciales posteriores al conflicto, las reformas en estas áreas fueron inadecuadas para fragmentar a las élites 
74 Revista de Paz y Conflictos $~$ ArTículos Originales

Souza, M. de A. C.; Mendes, C. G. B Building Peace Through the Nexus between Security, Democracy and Development...

locales, para evitar el desarrollo económico desigual y garantizar el bienestar horizontal para los liberianos.

Palabras clave: Construcción de paz, Operaciones de paz de la ONU, Paz, Seguridad, Desarrollo, Democracia, Liberia 


\section{Introducción 1}

The United Nations peace operations have undergone several institutional, normative and operational challenges since the early 1990s, to ensure that the challenges posed by intrastate wars were met. These disputes were often caused by structural and socially rooted inequalities and demand for access to power and land. Part of the new response of the UN to resolve intrastate warfare was the implementation of the mechanism of postconflict peacebuilding, aimed to carry out comprehensive peace accords to warrant sustainable peace, which would be achieved through the promotion of a set of state-building policies to restore state authority and to ensure post-conflict security, in addition to political and economic development. However, critical scholars has pointed to the insufficiency of this institutional-centered approach, arguing that the UN strategy is a top-down way to produce institutional peace that does not necessarily transform the everyday interaction between groups who have been previously engaged in warfare. In this paper, we intend to investigate whether the UN policies deployed to restore security and economic and political stability in post-conflict Liberia have actually strengthened local institutions and contributed to tackling the causes of the civil war in the country.

Thus, this paper consists of an interpretative case study of the United Nations Mission in Liberia (UNMIL), active between 2003 and 2018. The Liberian case is often regarded by the UN as a success case. Thus, the idea is to identify possible flaws in one of the most successful UN-led peacebuilding activities. Methodologically, this paper comprises an evaluation of official reports and mandates of UNMIL as an attempt to better assess the scope of action of the peace operation. After identifying the main sectors of action and overall orientation of the UNMIL, we have gathered secondary aggregated data to analyze whether the policies carried out during UNMIL were as effective as narrated by the Organization's official discourse. Although some adaptations were necessary to make the evaluation possible, aggregated data allows us to expose advances and setbacks achieved with the UN presence in Liberia.

The argument was structured into four topics. The first topic discusses two main peacebuilding modi operandi that have been on display in the past decades: the traditional approach and the critical one, which stresses the need for bottom-up approaches to building peace. Second, we present how the UNMIL's mandate reflects core assumptions of the traditional strategy as it focuses on institutional reforms targeting the establishment of democratic governance and promotion of economic development. The third section identifies advances and setbacks in Liberia to evidence whether the mission has implemented these reforms effectively. Finally, we present some conclusions.

\section{Peacebuilding: Theoretical Considerations}

There is great difficulty to reach a sole conceptualization of peacebuilding, as it encompasses a wide range of activities that are

1 This project was funded by a grant from the Coordenação de Aperfeiçoamento de Pessoal de Nível Superior (CAPES) and the Fundação de Amparo à Pesquisa do Estado de Minas Gerais (FAPEMIG). An earlier version of this paper was presented at the International Studies Association Annual Meeting in Toronto (2019). 
often implemented by different actors. In general, peacebuilding practice is aimed at constructing long-term peace after years of warfare. These activities include various reforms, such as “(...) development, security, legal and institutional reform, peace education, and indigenous peacemaking efforts" (Firchow and Anastasiou, 2016:1). Peacebuilding activities are closely linked with the concept of positive peace, first introduced by Johan Galtung (1969) in the $1960 \mathrm{~s}^{2}$, in which peace is conceptualized as the absence of social injustice in a society. In this ideal type of peace, this society would present, in Galtung's (1969: 183) words, an "egalitarian distribution of power and resources". Therefore, peacebuilding endeavors to achieve peace on a broader scale, and it is not limited to an understanding of peace as the absence of violent behavior (Höglund and Kovacs, 2010; Firchow, 2018). Thus, the peace that peacebuilders aim to build has a trait of being long-term and sustainable, targeting the "(...) prevention of new violent conflicts by transforming attitudes, behaviors, and norms in a direction that supports the peaceful regulation of conflict" (Höglund, Kovacs and Thiyagaraja, 2016: 11).

While there is a consensus that peacebuilding aims at achieving a positive and sustainable peace, the initiatives mobilized by peacebuilders towards such goal can vary significantly. Two main peacebuilding approaches have been on display in the past three decades, to which we refer here using Firchow's terminology (Firchow, 2018) of big-
P Peacebuilding and small-p peacebuilding. The former approach, adopted by the United Nations, is state-centric and intends to promote a set of institutional reforms in a vast range of sectors, with the belief that structural reforms are responsible for enhancing post-conflict stability (Newman, 2013; Firchow and Anastasiou, 2016; Firchow, 2018). Hence, this approach is focused on state-building activities ranging from bureaucratic and legal reforms to the construction of infrastructure in the wartorn state. Besides, policymakers in this particular type of peacebuilding are often oriented by the notion of "liberal peace", a Western model underpinned in the assumption that democratic and liberal values enshrine peace within societies (Mac Ginty, 2011; Firchow, 2018).

Accordingly, a peacebuilding process that relies on the liberal peace thesis is aimed at promoting structural reforms in five main areas: democracy, governance, human rights, rule of law and security sector (Mac Ginty, Joshi and Lee, 2019). Therefore, policies are deployed to ensure the implementation of democracy, revitalization and marketization of economy, and reform of the security sector (Pugh, 2009; Chandler, 2010; Mac Ginty, 2011; Gomes, 2013; Richmond, 2014; Smith, 2015; Firchow, 2018). Furthermore, this specific approach to establish peace in post-conflict societies concentrates its efforts on statebuilding policies oriented by a nexus of ontologically distinct variables (Stern and Öjendal, 2013) of security and sustainable peace linked to economic development (Kang,

2 According to Johan Galtung $(1969,1990)$, there are three types of violence: the personal violence, in which the actor and the victim of this violence are easily identifiable (one person shooting the other, for example); the structural violence, which involves discriminatory patterns of behavior in a society (privation or exploration of parts of the population, for example); and, lastly, the cultural violence, that is the one that legitimizes both the personal and structural violence, and it takes place especially through symbols and discourses (examples are homophobia, patriarchy, racism). 
2009) and democratic state-building (Mac Ginty, 2006).

Mac Ginty (2006) argues that the nexus linking democracy and peace has three underlying implications. First, the belief that democracies do not wage war between each other leads to a great optimism among states, inasmuch democracies are interpreted as the best alternative to cope with the security dilemma of anarchy. Second, inspired by the aforementioned teleology, international organizations have decided to place democracy as a universal remedy to insecurity and therefore peacebuilding processes became focused on (re)creating democratic regimes in the post-conflict context, even though international peacebuilders often find local resistance to the implementation of democratic procedures. Finally, the liberal peace assumption is understood as a mechanism of transmission and reproduction of Westernbased values particular of the routine of democratic societies ${ }^{3}$.

Economic development also started playing a central role in big-P Peacebuilding (Paffenholz, 2009) after many studies pointed out that economic recovery of countries lessens the likelihood of conflict parties to resort to violence, an argument sustained by a possible connection between violence and poverty. Hence, according to the liberal model that orients big-P Peacebuilding, appropriate economic conditions and welfare would be an essential feature of every peacebuilding process as it would prevent parties from resuming to violent behavior. Consequently, the pragmatic response of the big-P
Peacebuilding approach stresses the need for restoring state capacity to rebuild its market economy through the trade and financial liberalization (Kang, 2006).

However, critical studies on peacebuilding have challenged the liberal and top-down approach adopted by the UN. The implementation of a democratic and liberal "social engineering" to rebuild the social fabric has proved to be insufficient to achieve longterm peace (Paris, 1997; 2004; Krause and Jütersonke, 2005; Autesserre, 2010; Campbell and Peterson, 2013; Richmond, 2014; Millar, 2014; Kappler, 2014; Blanco, 2015; Tschirgi, 2015; Schulenburg, 2017). The fundamental critique is that whenever international-led peacebuilding projects are being designed, they often lack expertise about the everyday dynamics of the society benefiting from it. In the process of policy formulation, local knowledge is frequently marginalized, as local people tend to be excluded or not allowed to participate in such process, which results in a lack of local ownership (Richmond, 2010; Mac Ginty and Richmond, 2013; Pugh, 2013; Autesserre, 2014; 2017; Leonardsson and Rudd, 2015; Tom, 2017).

To cope with this problem, critical scholarship included the idea of a "local turn" in peacebuilding practice to put an end to the vertical processes carried out by international organizations (Lederach, 1997; de Coning, 2013; Paffenholz, 2015; Firchow, 2018). According to Lederach (1997: 94), "[t]he greatest resource for sustaining peace in the long term is always rooted in the local people and their culture". Thus, practitioners should

3 Layne (1994) poses other critiques to this security-democracy nexus. First, he argues that the absence of wars between democratic countries could be just a coincidence due to the low number of independent and democratic states until 1945. Second, he works with the possibility that the absence of wars might be intertwined with a lack of reasons or appropriate capacities for warfare. Finally, he mentions that the First World War took place between formal democratic regimes. 
contextualize policies to meet local demands, instead of imposing a set of norms and values imported from Western social and political realities (Lederach, 1997; Krause and Jütersonke, 2005; Mac Ginty, 2011; Mac Ginty and Richmond, 2013; Firchow, 2018). Similarly, Krause and Jütersonke (2005: 458) argue that "[a]sserting that a country is to be placed on the path towards liberal statehood does not help people in the street solve their daily existential dilemmas and will not be taken seriously by them". Therefore, this localcentered approach, hereafter small-p peacebuilding, focuses on agency and seeks to represent local demands in post-conflict contexts. Its core activities revolve around building relationships at the societal level through the promotion of national reconciliation and indigenous forms of peacemaking, a process usually spearheaded by Civil Society Organizations (CSOs) (Firchow, 2018).

According to the small-p peacebuilding approach, the achievement of sustainable peace requires more than institutional reforms, given that the dynamics surrounding conflicts are socially rooted and embedded in everyday interactions among individuals. Consistently, the societal model seeks to include local actors in the peacebuilding process. Thus, the main criticism of liberal peacebuilding is that it entails a top-down, homogenizing manner which does not consider the particularities of local agency (Mac Ginty, 2011; Mac Ginty and Richmond, 2013; Gomes, 2013; Richmond, 2014).

Furthermore, recent research evidenced an inadequacy between policies implemented by international peacebuilders and communal narratives of peace and insecurity. Data suggests that post-conflict communities measure everyday peace through anecdotal indicators that refer to contextual and hyper- local dynamics, albeit international peacebuilders keep on urging to focus on institutional reforms in spite of activities such as social healing and reconciliation, truthtelling, and reintegration (Mac Ginty and Firchow, 2016; Firchow and Mac Ginty, 2017; Firchow, 2018). Therefore, those in defense of the small-p peacebuilding strategy tend to argue that peace can only be achieved when the process of policy design takes into consideration the ordinary people's interpretations of peace. In this sense, the peacebuilding strategy would be tailored to address everyday local priorities. Therefore, this participatory approach engages directly with local data collection to design and reshape peacebuilding strategies for them to be effective when deployed in war-torn societies (Firchow and Mac Ginty 2017; Firchow 2018).

However, small-p peacebuilding activities are not exclusively local for two reasons. First, CSOs depend on external funding provided by international donors often from the Global North - to implement their activities. Hence, although CSOs carry out small-p peacebuilding tasks, the projects tend to depict the ideals and goals of their liberal donors (Vogel 2016; Firchow 2018). Second, CSOs do not often work independently in post-conflict zones. Their activities are often overseen by International Non-Governmental Organizations (INGOs), which also tend to operate based on a liberal and top-down orthodox approach. Notwithstanding, CSOs carry out activities in a similar way as INGOs, often constrained by international donors seeking to diffuse a liberal world-view (Mac Ginty, 2010; Firchow, 2018).

Therefore, much has been discussed on the complementarity between these two approaches. For example, the promotion of human rights in post-conflict settings is a recurrent theme and often seen as mandatory in 
both approaches, since local actors might have had their rights and bodies violated during warfare. However, small-p peacebuilders may argue that it is preferable to yield peacebuilding practice towards a contextualized version of human rights that can meet the expectations of the everyday people. Therefore, although it is common to identify some traits of a liberal agenda in peacebuilding processes funded by liberal organizations (Ryan, 2013), the content of the project should not be driven solely by their beliefs and should not invalidate local knowledge and bottom-up perspectives (Mac Ginty, 2011; Mac Ginty and Richmond, 2013; Richmond, 2014).

This complementarity is possible because democratization and economic liberalization, assumptions of the big-P Peacebuilding approach, and the small-p peacebuilding activities are not binary opposites. Indeed, Mac Ginty, Joshi and Lee (2019) argue that when peace agreements include provisions in the areas of the rule of law, human rights, democracy, security and governance, it can increase the likelihood of post-conflict peace in cases in which the implementation runs smoothly. The small-p peacebuilding approach argues that the failure of international peacebuilding is the absence of local inclusion in the process of policy design. Hence, the lack of ownership is the result of local exclusion in these attempts, and big-P Peacebuilding processes tend to create a knowledge hierarchy in which the ideas of liberal policymakers are considered as progressive and key to success, while the local knowledge is often portrayed as non-scientific and trivial (Autesserre, 2017; Mac Ginty, 2018).

\section{The UN Peacebuilding Mission in Liberia}

The armed clashes between the Government of Liberia (GOL), headed by President Charles Taylor, and non-state armed groups led both parties to the Second Liberian Civil War (1999-2003). Liberia was a country with a history of inequality in economic, political and social dimensions. From the late 1980 s to the end of the civil war in 2003, Liberia was also known as a corrupt country, with massive human rights violations, committed by both non-armed groups and government security forces, the latter often attending to the President's personal requests to attack the opposition (Souza, 2018; Foster et al, 2009; Nilsson, 2009). The main sources of conflict between the GOL and the Liberian society were related to the absence of democratic governance, unequal distribution of national wealth and the abuse of political power. Therefore, the armed opposition, composed mainly by military personnel who were sent into exile by President Taylor, formed two main armed groups with a shared goal: to withdraw Taylor from power. The two main groups in the Second Liberian Civil War were the Liberians United for Reconciliation and Democracy (LURD) and the Movement for Democracy in Liberia (MODEL) (Nilsson, 2009; Sayle et al, 2009).

The year of 2003 was critical for the government forces, given the fact that almost $70 \%$ of the Liberian territory was already controlled by armed militias. While the GOL was losing territorial control, armed groups had gradually approximated to the capital of Liberia, Monrovia, seeking to depose Taylor. Taylor's resignation was a precondition imposed by armed groups to initiate peace talks. Pressured by the situation, Taylor stepped down and resigned from his 
presidential role on August 11, 2003, ceding his office to the Vice-President Moses Blah. This move was critical for armed groups to engage in the negotiation of a peaceful settlement for the war. Therefore, on August 18,2003 , the parties decided to seal the end of the Second Liberian Civil War through a Comprehensive Peace Accord (CPA), signed in the Ghanaian city of Accra (CPA, 2003; Waugh 2011; Harris 2012).

Throughout the dispositions of the CPA, parties asked for international support to implement the agreement and rebuild Liberia in the post-conflict context (CPA, 2003). The United Nations (UN) responded to this request and recommended for the UN Security Council
(UNSC) to establish a multidimensional peace operation in post-conflict Liberia, a demand readily accepted by its members (UN 2003a; $2003 \mathrm{~b} ; 2003 \mathrm{c}$ ). The first mandate of the United Nations Mission in Liberia (UNMIL) divided peacebuilding activities into five main components (Table 1): cease-fire activities; security sector reform; human rights and humanitarian relief (rule of law after 2007); peace process; support affairs (UN 2003c). Except for the cease-fire component, that was excluded from annual updates after the completion of this task, all other activities remained until the official closing of the mission in 2018.

TABLE 1: UNMIL MAIN TASKS BY COMPONENT 4 (SOURCE: OWN ELABORATION, BASED ON UN 2003D; 2004A; 2004B; 2006; 2007; 2008; 2009; 2010; 2011; 2012; 2013; 2014; 2015; 2016; 2017)

\begin{tabular}{|c|l|}
\hline \multirow{4}{*}{ Cease-fire } & Demobilization, Disarmament, Rehabilitation and Reintegration (DDRR) \\
\cline { 2 - 3 } Security Sector Reform & Provision of security \\
\cline { 2 - 3 } & Infrastructure for security forces \\
\cline { 2 - 3 } & Provision of security \\
\cline { 2 - 3 } Rule of Law & Reform of the correctional framework \\
\hline \multirow{3}{*}{ Peace Process } & Human rights provision \\
\cline { 2 - 3 } & Humanitarian assistance \\
\cline { 2 - 3 } & Reform of Liberia's legal framework \\
\cline { 2 - 3 } & Reconciliation tasks \\
\hline & Reform of state institutions \\
\cline { 2 - 2 } & Support and hold elections \\
\hline
\end{tabular}

As Table 1 demonstrates, the mandate of the UNMIL focused on state-building activities with a twofold focus. First, the mandate was closely related to security tasks to warrant the reduction of violence in the country, given the strategies to be implemented under the Ceasefire and Security Sector Reform components. Second, through the components of Rule of Law and Peace Process, UNMIL proved to be extremely focused on the implementation of

4 The field support component will not be included in the analysis as it was focused exclusively on administrative, logistical and technical support to civilians and UN personnel. 
the Rule of Law, democracy and human rights. Aside from the core activities carried out directly by the UNMIL and its representatives, development-related strategies were designed to restore welfare and economic development.

\subsection{Liberian State-building}

In a post-conflict environment, to ensure the fragmentation of elites, peacebuilding tasks often include several far-reaching reforms to build or restore power-sharing structures in economic, military and political sectors. Hence, the democratization of access is often the path chosen by policymakers to promote inclusion in societies historically impaired by inequality and uneven opportunities (Wallensteen, 2007; Derouen Jr, 2015). In the Liberian case, democratization was an imperative feature of the big-P Peacebuilding led by the UN. In 2007, after the conclusion of the disarmament process, the UN directed its attention towards broader reforms in the security sector, as Liberia was a country composed by approximately sixteen different ethnic groups, but the security forces were dominated by only two of them. Besides its operational dimension of providing training and infrastructure for security forces, the reform also offered entry opportunities for members of historically marginalized ethnic groups. Therefore, the process of democratization in the country was not only aimed at restoring the formal democracy in Liberia, but also at diffusing democratic values at the societal level (UN 2003d; 2007; 2008; Waugh, 2011).

Concerning the "Peace Process" component, the mandate stressed the need to trace a strategy linking a wide range of sectors to ensure a peaceful transformation in the country. According to the mandate, UN personnel would be responsible for strengthening state authority through institutional reforms seeking to restore its capacity to ensure the jurisdiction at the national level. The operation was also responsible for reestablishing the entire justice system, for example its prison and justice institutions, to ensure human rights protection and proper accountability in the post-conflict context. Finally, the UNMIL was also assigned to build and sustain a peaceful environment for holding elections, a procedure to ensure the rule of law in post-conflict Liberia (UN 2003d). The association of the aforementioned functions as part of the component labelled as "Peace Process" demonstrates the direct link established between peace and the strengthening of democratic/justice institutions. Thus, the state-building process in Liberia exceeded creating a stable environment for holding elections, but also encompassed tasks to (re)build institutions identified in democratic societies.

The peace operation was also assigned to stimulate the protection of human rights and the provision of humanitarian relief, tasks carried out by members of the "Human Rights and Humanitarian Relief" component (UN $2003 c ; 2003 d)$. Therefore, beyond the implementation of the democratic regime, the UNMIL also concentrated its efforts in building capacity among officials of the Liberian government that would have to comply with international norms and treaties in this regard. Thus, one can infer that this attempt to create or restore capacity to human rights is a result of an imposition of the liberal agenda that orients the process of policy formulation and implementation of the big-P Peacebuilding approach, thereby evidencing the verticality in which the process is conducted on the ground.

To make the peace process more inclusive to local organizations and 
individuals, the UNMIL funded several Quick Impact Projects (QIPs), responsible for tackling the basic needs of local communities. Although financed by the UN, these projects are more locally-sensitive as they are conducted by CSOs and/or local authorities. Therefore, QIPs are an attempt to build postconflict peace from the bottom-up, since it encourages local participation, and thus local ownership. However, albeit guided by CSOs and local authorities, the requirement for authorizing funding was that QIPs had to fall into the general spectrum of activities foreseen in the mandate, thereby suppressing the possibility of a truly local initiative funded by the UN (DPKO and DFS, 2017).

Between 2005 and 2017, the organization authorized 720 QIPs in Liberia (UNMIL 2016a; 2016b; 2017). In Figure 1 below we have classified the QIPs authorized in Liberia between 2005 and 2018 based on how each project contributed to a specific core activity of UNMIL and also on the contributions of these projects to the overall mandate of the peace operation. Projects are majorly connected with the Peace Process component, as 360 QIPs were authorized to conduct parallel activities to support elections and restore state authority and capacity. Most of the projects have invested in infrastructure and training activities to ensure the appropriate capacity of public employees. Training programmes sought to strengthen the judiciary and legislative bodies, build capacity in the rule of law sector, and revitalization of the local economy. Another 184 projects were responsible for creating conditions for security forces to operate. The content of these projects revolves around the construction of police stations and army units and the promotion of training of officials of security forces. The purpose of these QIPs was not limited to technical and operational training and support, and it often encompassed the funding of workshops in which security forces were taught on how to conduct their functions in an impartial and democratic way. The other 176 projects approved sought to consolidate the rule of law. An interesting note is that in the early years of the operation, particularly from July 2005 to June 2006, more than half of the QIPs were related to the provision of humanitarian relief and promotion of human rights. The content of these projects was to a large extent related to the provision of basic human rights, such as access to health, education, safe drinking water and electricity, post-conflict emergency issues (UNMIL 2016a; 2016b; 2017).

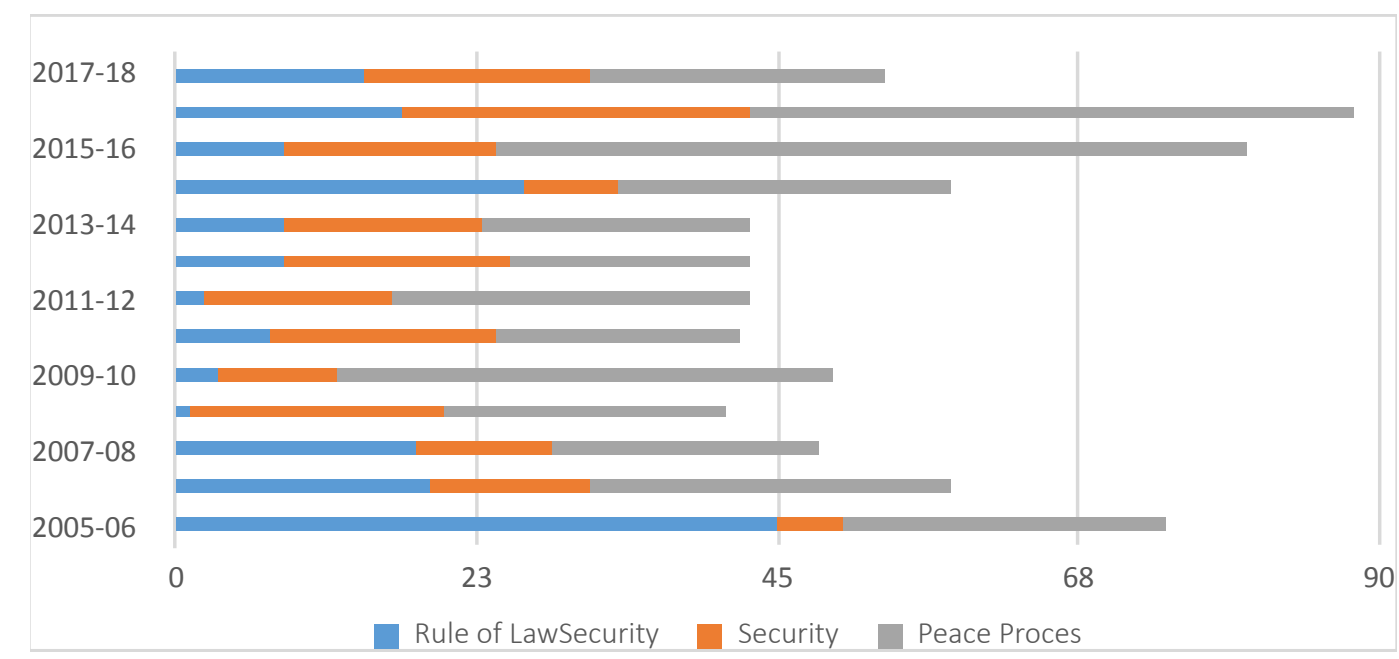

FIGURE 1: QIPS AUTHORIZED WITHIN UNMIL'S FRAMEWORK (2005-2018) (SOURCE: OWN ELABORATION, BASED ON UNMIL 2016A; 2016B; 2017) 


\subsection{Development Assistance}

In sum, the main goal of UNMIL peacebuilding activities contemplated by different components was to promote the reconstruction of state institutions. Most specifically, there was a focus on institutions responsible for ensuring the operational procedures of a functional rule of law: reforms on the institutional level to establish state authority to foster respect for human rights, diffusion of democratic values in the security sector reform, build capacity to ensure the operation of the justice and legislative bodies, and the promotion of periodic elections at both regional and national levels. Therefore, the process of big-P Peacebuilding in Liberia does focus on state-building tasks, that interlink the strengthening of institutions to long-term peace, which stresses the UN tendency to comply with the liberal peace teleology whenever peace operations assume postconflict duties (UN, 2003d; 2004a; 2004b; 2006; 2007; 2008; 2009; 2010; 2011; 2012; 2013; 2014; 2015; 2016; 2017).
Development assistance was a central matter in the process of state-building in Liberia, as the UN system has often associated poverty, underdevelopment and inequality as sources of hatred and warfare in intrastate conflicts (Paffenholz, 2009; Kang, 2009). In Liberia, one of the triggers of inter-communal grievances that resulted in two civil wars in a short period of time was indeed connected with horizontal inequalities and the concentration of economic wealth by those in power (Souza, 2018). Therefore, the development assistance community tried to address this structural cause of conflict and established three development assistance plans seeking to attain socioeconomic justice and promote economic growth in Liberia. Development assistance plans (Table 2) were implemented in close coordination between UNMIL, local authorities and international donors and financial institutions (UNDAF Liberia, 2003; 2007; 2012).

TABLE 2: UN DEVELOPMENT ASSISTANCE FRAMEWORK (UNDAF) LIBERIA MAIN FOCUS (2003-2017) (SOURCE: OWN ELABORATION, BASED ON UNDAF LIBERIA 2003; 2007; 2013)

\begin{tabular}{|l|l|}
\hline \multirow{2}{*}{$2003-2005$} & Conflict resolution, peacebuilding and relief \\
\cline { 2 - 3 } & Good governance \\
\cline { 2 - 3 } & Food security and economic recovery \\
\cline { 2 - 3 } & Reproductive Health, AIDS, malaria and other diseases \\
\hline Cross-cutting issues: gender; natural resources; children \\
\hline Peace and Security \\
\cline { 2 - 2 } & Equitable socioeconomic development \\
\cline { 2 - 3 } & Good governance and rule of law \\
\hline Education and health \\
\cline { 2 - 3 } & Prevention, Treatment and Care of HIV / AIDS \\
\hline
\end{tabular}




\begin{tabular}{|c|c|}
\hline & $\begin{array}{l}\text { Cross-cutting issues: gender equality; female empowerment; environment and } \\
\text { sustainable development; youth and capacity building }\end{array}$ \\
\hline \multirow{5}{*}{$2013-2017$} & Peace, security and rule of law \\
\hline & Sustainable economic transformation \\
\hline & Human development \\
\hline & Inclusive governance and public institutions \\
\hline & $\begin{array}{l}\text { Cross-cutting issues: gender equality; human rights; environment; employment; } \\
\text { reconciliation. }\end{array}$ \\
\hline
\end{tabular}

The first UNDAF Liberia (2003-2005) recognizes that social and economic inequality among the various ethnic-religious groups in Liberia was one of the latent causes of the civil war, and thus the UNDAF plans sought to address this issue. Consistently, the development strategy comprised the promotion of good economic governance through the strengthening of government institutions and restoration of vital sectors in Liberia, such as manufactures and industry, both inoperative due to the widespread destruction of the country's infrastructure during the civil war. Furthermore, the establishment of infrastructure conducive to development would enable the Liberian market to operate and rehabilitate the economy, a priority of UNMIL in its early years (UNDAF Liberia, 2003).

Right after the signature of the CPA, the Liberian economic sectors were still in a critical situation due to the country's inability to operate properly during the civil war. Hence, in 2003, the country was facing high rates of unemployment, undernourishment and inequality. Therefore, the first UNDAF plan for Liberia sought to revitalize the market, a twofold attempt that could both stimulate job creation and supply the local population undergoing a severe food crisis. As a result, two reforms were placed at the forefront of this initial phase of development: the establishment of new macroeconomic policies to restore and stimulate production by the private sector, and the reconstruction of infrastructure to enable the economic activity of small and mediumsized companies. Consistent with its liberal orientation, the first development plan defended the reduction of state constraints to the private sector, and the authorization of microcredits for private producers to resume agricultural and manufacture production. In the plan, there was also pledge for immediate trade liberalization to increase the exports in order to ensure food security and promote the development of the national economy (UNDAF Liberia, 2003). The first UNDAF plan also stressed the need to modernize the production structure. Modernization would thereby increase the capacity of small companies to supply the local market, export their products, and also to reduce unemployment, as expanded production would also increase the demand for labor. For this nexus between unemployment and development to work, the assistance plan required: (1) market liberalization; (2) privatization and the reduction of the role of the state in managing the economy; (3) stimulation of economic competition between local businesses which would be funded by the microcredit conceded by international institutions (UNDAF Liberia, 2003).

The second UNDAF for Liberia (2008-2012) intended to operationalize strategies mobilized in the 2007 document "Interim Poverty Reduction Strategy Paper", 
elaborated by the Liberian government in partnership with major financial institutions, such as the International Monetary Fund (IMF) and the World Bank (Liberia 2007; UNDAF Liberia 2007). Although the purpose of the document was to mitigate poverty and its underlying consequences, the following passage demonstrates an inconsistency between its allegedly aims and means adopted: "[e]ven if economic growth will be pro-poor, it is well recognized that not all poor people are able to participate in the growth or access its benefits. This is particularly true for the most vulnerable, including the very young, the old, those with disabilities and those unable to work" (UNDAF Liberia 2007: 18). Taking that into account, we can see that there is a paradox inasmuch the development plan indirectly states that the policies outlined would not be sufficient to tackle social injustice among Liberian citizens - especially those considered as a poor workforce. However, this assistance plan does not tackle this issue and continues to reinforce the need for fast economic development. To do so, it encouraged the increase in funding to ensure competition between small and medium scale companies, which would enhance their production capacity, and in consequence, commodities could be commercialized to supply both local and international demands. Therefore, the UN official discourse presents this strategy of market liberalization as a sine qua non condition for development, even though acknowledging that it would not tackle the problem of horizontal inequality (UNDAF Liberia, 2007).

Finally, the third UNDAF for Liberia (2013-2017) did not bring about great variation compared to the other two plans. As a result, the development assistance kept sustaining UN's key pillars regarding the promotion of democratic economic governance, revitalization of established companies through the concession of microcredits, and maintenance of incentives for competitiveness to ensure internal competition, specialization and productive capacity. Although the propositions for post-conflict economic management do not vary greatly in their nature, the final development plan complements the liberal feature of the process in two ways. First, it emphasized the need to remove statist policies that could constrain Liberian entrepreneurs. Thus, it points to state minimal participation in the economic sphere, which evidences the liberal influence guiding the implementation of the big-P Peacebuilding in the field. Second, and paradoxically, it asserts the need to achieve equitable participation of individuals in social, political and economic areas until 2017. This is a point of controversy as the previous assistance plan admitted citizens could not benefit evenly from the development and economic growth (UNDAF Liberia, 2012).

\section{Assessing the Effectiveness of the UN Peacebuilding in Liberia}

This section aims to investigate whether the liberal orientation of the big-P Peacebuilding contributed to addressing the conflict causes in Liberia. Thus, in order to explore this objective, this section relies on aggregated data from the Fragile State Index (FSI), coordinated by the Fund for Peace (FFP). The indicators are placed together into four main groups: "Cohesion", "Economic", "Political", and "Social and Cross-Cutting", and in each area numbers from 0 to 10 are attributed to evaluate the situation. The number " 0 " represents the best scenario, while "10" is the worst situation possible (FFP, 2019). Each of these broader groups comprises three variables. The "Cohesion" indicators take into consideration 
the Security Apparatus (C1), Factionalized Elites (C2) and Group Grievance (C3). The economic indicators evaluate the Economic Decline (E1), Uneven Economic Development (E2), Human Flight and Brain Drain (E3), while political indicators include "State
Legitimacy" (P1), "Public Services" (P2), "Human Rights and Rule of Law" (P3). As Table 3 demonstrates, we will first analyze the "Political" and "Cohesion" categories to better grasp the effectiveness of the UN in restoring the Liberian state.

TABLE 3: INDICATORS AND DIMENSIONS WITHIN THE UNMIL'S SCOPE (SOURCE: OWN ELABORATION, BASED ON UN 2003D; 2004A; 2004B; 2006; 2007; 2008; 2009; 2010; 2011; 2012; 2013; 2014; 2015; 2016; 2017)

\begin{tabular}{|c|c|c|}
\hline Dimension & Tasks & Indicator \\
\hline \multirow{2}{*}{ Cease-fire } & $\begin{array}{l}\text { Demobilization, Disarmament, Rehabilitation and Reintegration } \\
\text { (DDRR) }\end{array}$ & $\mathrm{C} 1, \mathrm{C} 2$ and $\mathrm{C} 3$ \\
\hline & Provision of security & $\mathrm{C} 1$ \\
\hline \multirow{4}{*}{$\begin{array}{l}\text { Security Sector } \\
\text { Reform }\end{array}$} & Democratization, reform and training of the army and police forces & $\mathrm{C} 2, \mathrm{P} 1$ and $\mathrm{P} 3$ \\
\hline & Infrastructure for security forces & $\mathrm{C} 1$ \\
\hline & Provision of security & $\mathrm{C} 1$ \\
\hline & Reform of the correctional framework & $\mathrm{C} 2, \mathrm{C} 3, \mathrm{P} 1$ and $\mathrm{P} 3$ \\
\hline \multirow{4}{*}{ Rule of Law } & Human rights provision & $\mathrm{P} 1, \mathrm{P} 2$ and $\mathrm{P} 3$ \\
\hline & Humanitarian assistance & $\mathrm{P} 2$ and $\mathrm{P} 3$ \\
\hline & Reform of Liberia's legal structure & $\mathrm{C} 2, \mathrm{C} 3, \mathrm{P} 1$ and $\mathrm{P} 3$ \\
\hline & Reconciliation tasks & $\mathrm{C} 3$ and $\mathrm{P} 3$ \\
\hline \multirow{2}{*}{ Peace Process } & Reform of state institutions & $\mathrm{P} 1$ and $\mathrm{P} 3$ \\
\hline & Organize elections & P1 and P3 \\
\hline
\end{tabular}

Regarding the "Cohesion" dimension, the main progress made is related to the indicator "Group Grievance", which has been decreasing significantly since 2014. This indicator is a relevant one inasmuch it evidences that the activities carried out by the UN and partner organizations prompted a positive impact towards national reconciliation in Liberia. Concerning the "Security Apparatus", there is a significant improvement compared to previous years, and therefore one can argue that there is a positive correlation between this improvement and the UNMIL's investments in the disarmament and reform of the security forces. However, when we take into consideration the "Factionalized Elites" indicator, little progress has been achieved, which shows that the UN was not able to tackle effectively one of the main causes of the Liberian civil war, which is the horizontal inequalities between local elites and lessprivileged groups. Therefore, one may infer that the liberal perspective adopted in Liberia was insufficient to redistribute power. This might be correlated with the fact that the UNDAF and its partners authorized microcredits to companies which already existed before warfare, maintaining the status of the elites in the post-conflict phase. Hence, it hindered the population from taking part in the benefits of economic development evenly. 


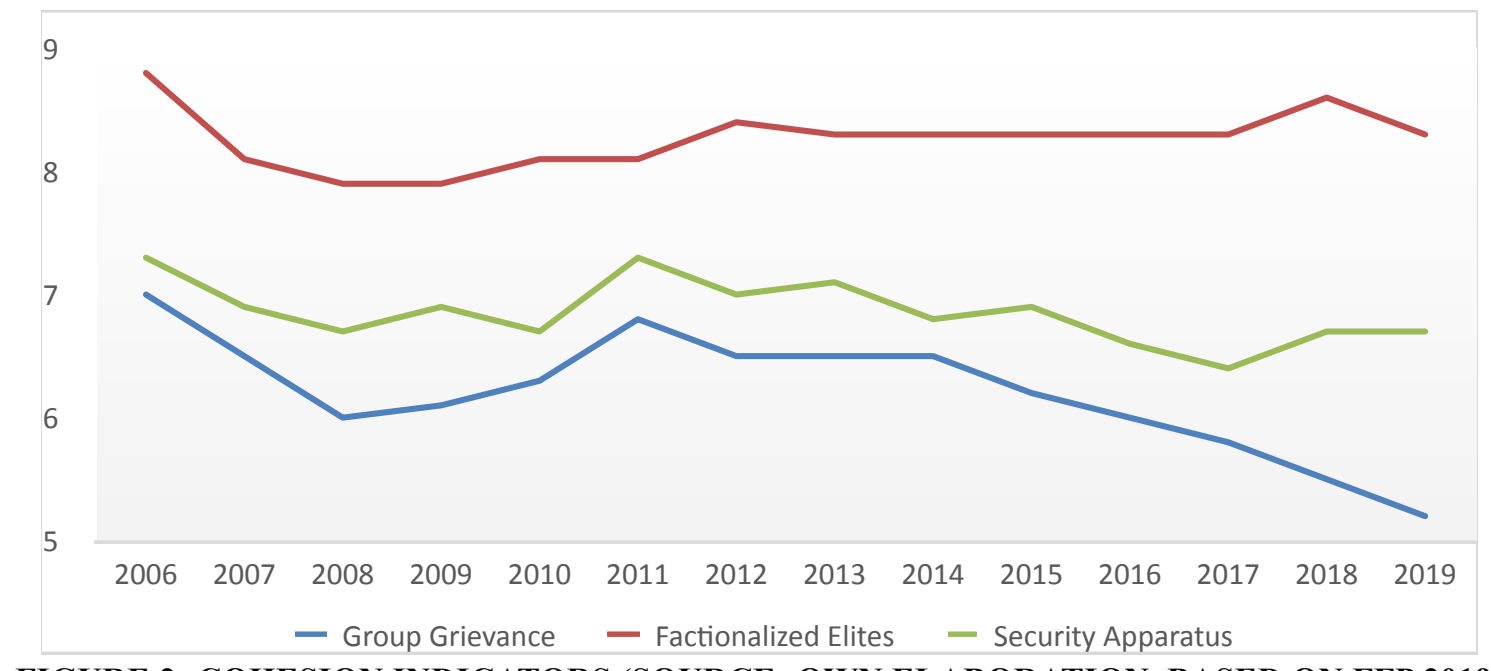

FIGURE 2: COHESION INDICATORS (SOURCE: OWN ELABORATION, BASED ON FFP 2019)

The indicators that characterize the political situation of post-conflict Liberia have demonstrated an improvement in two main areas since 2006: "Public Services" and "Human Rights and Rule of Law". Indeed, this improvement comes as no surprise, given that, as discussed earlier, a large part of UN policies was related to strengthening the state apparatus in order to ensure certain effectiveness in public services and to protect human rights. However, it is relevant to mention that the Liberian capacity to provide public services to its population nowadays equals their capacity in 2006, demonstrating that, in this sphere, UNMIL's and UN agencies peacebuilding efforts have not had significant impact. Besides the improvement of the Liberian situation in these two variables since 2015, the third indicator considered by the database is "State Legitimacy", and data indicates a tendency of improvement in this category especially after 2015. However, the underperformance in "Public Services" in Liberia exceeds the UN peacebuilding project due to the outbreak of the Ebola crisis in the country between 2013 and 2016. The Liberian health system, which was already one of the most fragile in the world, had difficulties to provide services and was highly dependent on humanitarian aid from organizations such as Médecins sans frontières in that period (MSF, 2016).

However, considering the set of Political indicators, we can infer that the UNMIL was not able to promote linear progress. This can be partially explained by the short-term existence of democratic processes in the country and the fact that the elections held in 2017 were marked by judicial appeals, which delayed the second round for the presidential election by almost two months. Another aspect to be considered is that during both the run and runoff of the elections, anti-minorities discourses were uttered by candidates - such as discourses against the LGBTI community (The Carter Center, 2017). These factors obviously undermine people's confidence in the legitimacy of the state and democratic processes, and therefore are a problem that has to be reassessed in the future. 


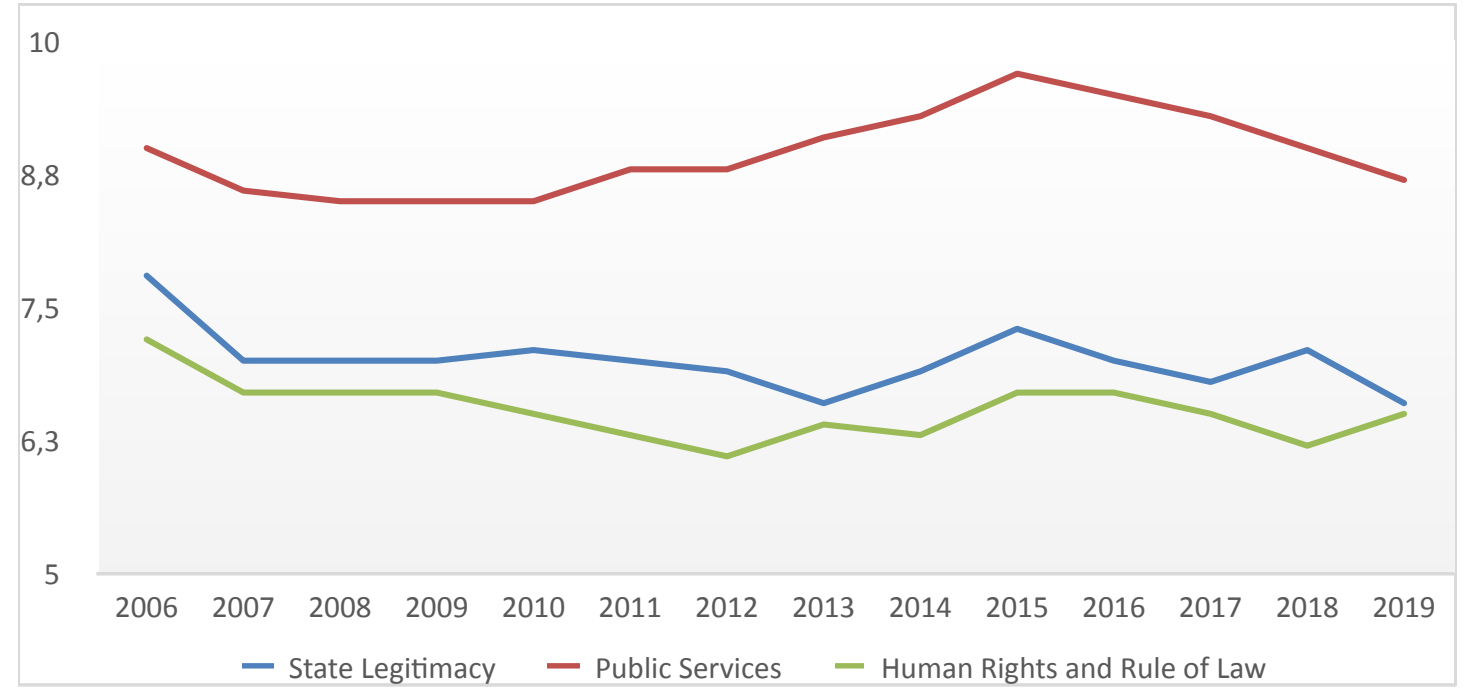

FIGURE 3: POLITICAL INDICATORS SOURCE: OWN ELABORATION, BASED ON FFP (2019)

Conclusively, we can observe that UNMIL and $\mathrm{UN}$ agencies peacebuilding policies assisted in preventing the resumption of armed conflict in Liberia, for example by contributing to a decrease in group grievance $(7,0$ in 2006 and 5,2 in 2019) and through the policies deployed to restore and reform the security forces. However, especially the fragmentation of elites, which is a crucial move considering the roots of the conflict, the mission has achieved little progress during the UN activity in Liberia. Notwithstanding, it is important to keep observing whether this tendency of inequality will remain in the coming years.
The state-building in Liberia, as argued above, was placed alongside three development assistance plans, evidencing the peacedevelopment nexus embedded in the UN big-P Peacebuilding thought. To better assess the effectiveness of UN policies in the economic sphere, we will exceed the evaluation of the indicators of the Fragile States Index, to also scrutinize aggregated data from the World Bank, FAOSTAT, and Human Development Index (HDI), distributed according to the scope of activities foreseen in the development assistance plans (Table 4).

TABLE 4: INDICATORS AND DIMENSIONS WITHIN THE UNDAF'S SCOPE (SOURCE: OWN ELABORATION, BASED ON UNDAF LIBERIA 2003; 2007; 2012)

\begin{tabular}{|l|l|l|}
\hline Dimension & Tasks & Indicator \\
\hline \multirow{4}{*}{$2003-2005$} & Conflict resolution, peacebuilding and relief & $*$ \\
\cline { 2 - 3 } & Good governance & World Bank \\
\cline { 2 - 3 } & Food security and economic recovery & FAOSTAT, E1 \\
\cline { 2 - 3 } & Reproductive Health, AIDS, malaria and other diseases & HDI \\
\cline { 2 - 3 } & Cross-cutting issues: gender; natural resources; children & E2 \\
\hline & Peace and Security & $*$ \\
\cline { 2 - 3 } & Equitable socioeconomic development & $*$ \\
\cline { 2 - 3 } & Good governance and rule of law & E2 \\
\cline { 2 - 3 } \\
\cline { 2 - 3 }
\end{tabular}




\begin{tabular}{|l|l|l|}
\cline { 2 - 3 } $2008-2012$ & Education and health & HDI \\
\cline { 2 - 3 } & Prevention, Treatment and Care of HIV/AIDS & HDI \\
\hline $\begin{array}{l}\text { Cross-cutting issues: gender equality; female empowerment; } \\
\text { environment and sustainable development; youth and capacity building }\end{array}$ & E2; HDI \\
\hline \multirow{2}{*}{$2013-2017$} & Peace, security and rule of law & $*$ \\
\cline { 2 - 3 } & Sustainable economic transformation & HDI \\
\cline { 2 - 3 } & Human development & HDI \\
\cline { 2 - 3 } & $\begin{array}{l}\text { Inclusive governance and public institutions } \\
\text { Cross-cutting issues: gender equality; human rights; environment; } \\
\text { employment; reconciliation. }\end{array}$ & E2 \\
\hline
\end{tabular}

In every development assistance plan, the peacebuilding project focused dearly in the promotion of "Good Governance" in Liberia. In World Bank data, this category encompasses six variables: (1) Control of Corruption; (2) Government Effectiveness; (3) Political Stability and Absence of Violence/Terrorism; (4) Regulatory Quality; (5) Rule of Law; (6) Voice and Accountability. Considering these six indicators, one can infer that there was a significant improvement to ensure post-conflict "good governance". This argument is sustained by the fact that at the beginning of the mission in 2003, the country was known to have the lowest performance in all six dimensions. However, it is important to mention that the improvement in Liberia is not necessarily linear - the years of 2014 and 2015, for example, expose a decrease in performance, but this decrease might also be linked to external issues such as the Ebola crisis. Despite this observation, it is possible to identify a significant and general improvement enhanced by the structural reforms foreseen in the big-P Peacebuilding strategies implemented by UNDAF and partner organizations.

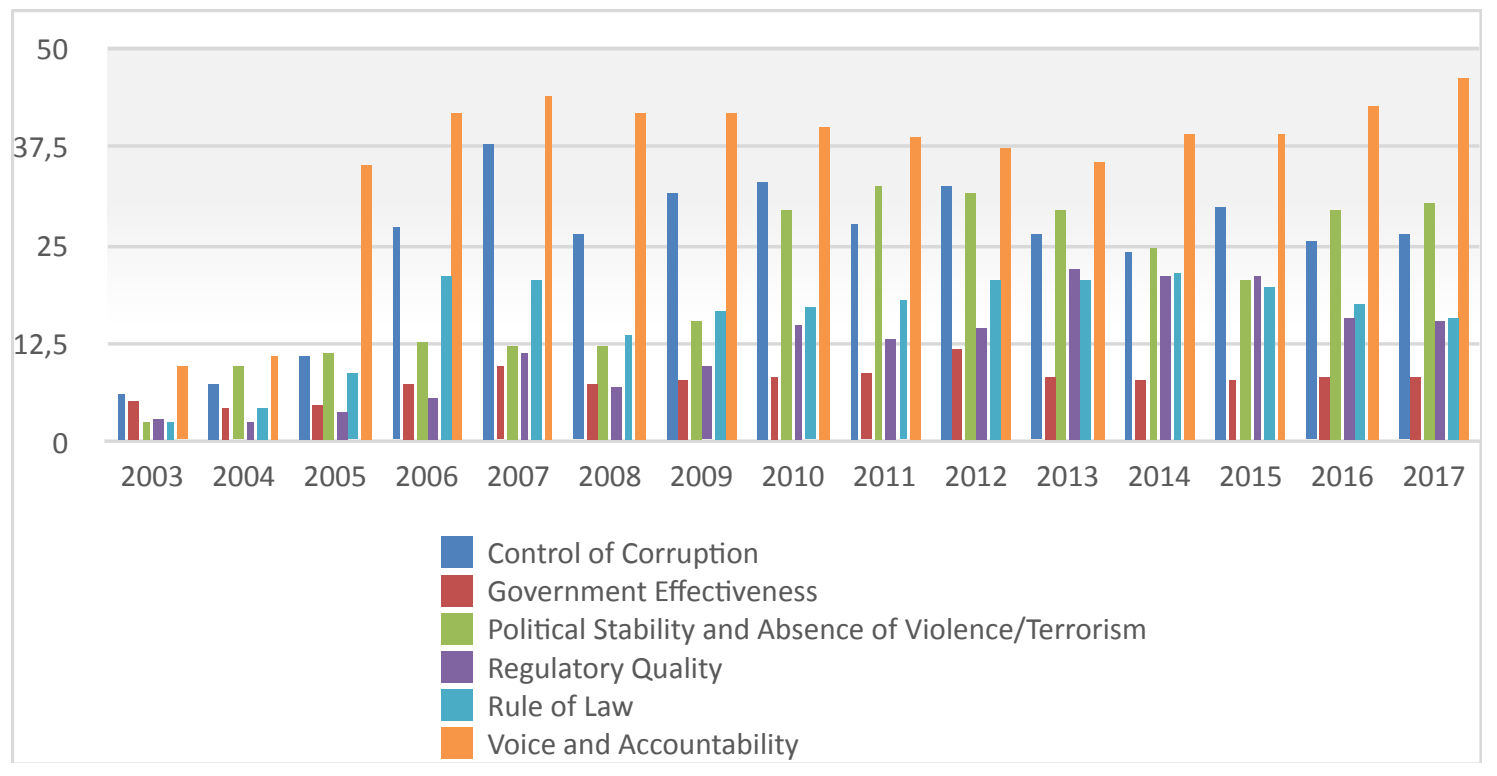

FIGURE 4: GOVERNANCE IN LIBERIA (2003-2017) IN PERCENTILE RANK (\%) (SOURCE: OWN ELABORATION, BASED ON WORLD BANK 2019). 
Through the economic indicators of the Fragile States Index (2019), it is possible to identify an overall improvement in two variables: "Economic Decline" (E1) and "Uneven Economic Development" (E2). Despite the overall advancement in these two spheres, there was great variation in them between 2006 and 2018. First, the situation of Liberia concerning the uneven economic development achieved its best mark in 2012, when the value attributed was 7.7. In the following years, however, we can note a significant decrease in performance until 2016. Surprisingly, the year 2013 marks the period in which the development assistance plan emphasized the need for a minimal state in Liberia. Therefore, while the UN and its partner organizations advocated for the absence of statist constraints in the economic sphere, the development process in Liberia faced a setback in terms of horizontal distribution of economic benefits.
Second, the process was slow, especially if we compare the small variation throughout the years. In 2006, data indicated the value 8,9 to characterize the 'Economic Decline', and 12 years after, there is a small improvement of 0,8 concerning this indicator. Regarding the variable "Uneven Economic Development", the impact is even lower - from 8.6 in 2006 to 8.1 in 2018. Thus, compared to the advances made in the "Political" and "Cohesion" dimensions, development policies seem to have been less effective as indicators remain high and there has been little variation over the years. Conclusively, to avoid economic decline and to promote equality in the economic spheres, strategies towards marked liberalization and absence of the state in the economic sphere are strategies that do not seem to contribute to tackling the causes of the warfare in Liberia.

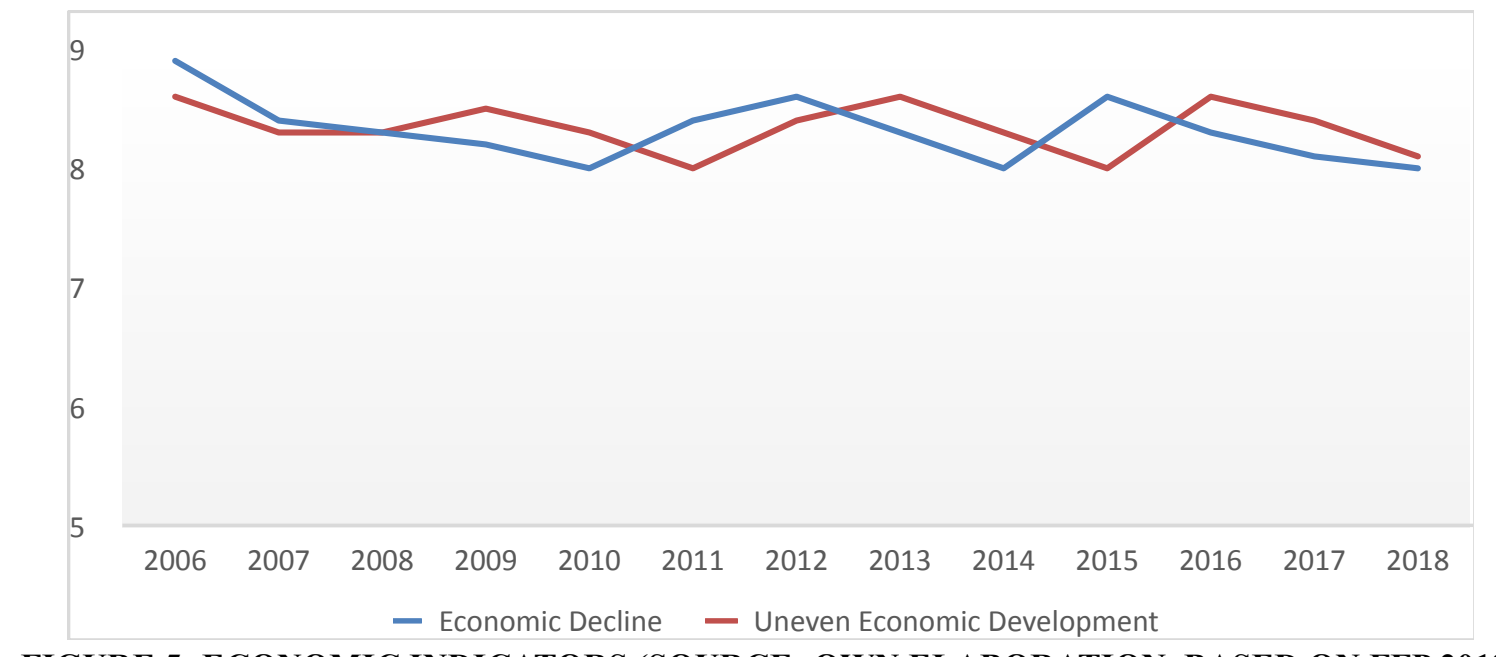

FIGURE 5: ECONOMIC INDICATORS (SOURCE: OWN ELABORATION, BASED ON FFP 2018)

Since food insecurity was a severe problem in post-conflict Liberia, the UNDAF plans addressed this issue in the three phases of development assistance. To deal with this humanitarian issue, as we have discussed above, big-P Peacebuilding policies were deployed to warrant a fast economic recovery and market liberalization. These two measures would, according to the UN, tackle underemployment and give citizens the means to access food. To better assess whether these policies were efficient, we have to consider two dimensions: the prevalence of undernourishment in percentile rank and the 
total number of people undernourished. Considering the first dimension, in 2003, $40.7 \%$ of the population was undernourished, and, after fifteen years, this number decreased slightly to $37.2 \%$. On the other hand, regarding the number of malnourished people, the situation has been deteriorating since 2003. In 2003, 1.3 million Liberians were in this situation, while in 2018 Liberia achieved its peak in this regard with 1.8 million in a condition of undernourishment (FAOSTAT, 2019). Hence, albeit Liberia is now in a greater economic situation, this improvement did not impact on food supply and starvation.

Finally, the Human Development Index (HDI) comprises a wide range of dimensions, which are Health, Education, Income/ Composition of Resources, Inequality, Gender, Poverty, Work, Employment and Vulnerability, Human Security, Trade and Financial Flows, Mobility and Communication, Environmental sustainability, Demography, and Socioeconomic Sustainability (UNDP, 2019). The index is composed of a scale from 0 to 1 , in which 1 represents the ideal situation, while 0 represents the worst scenario. Although there is a linear improvement of the HDI in Liberia between 2003 and 2017, the advance in this indicator was extremely low if we compare to the beginning of UN activities in Liberia, when the number attributed to Liberia was 0.387 . This number remained constant until 2009, which is when we can observe a minimal improvement. In 2017, HDI in Liberia was 0.435 - an improvement of the Liberian situation in 0,048 . The world average, according to UNDP, is 0.728 , thus demonstrating that Liberia is still in a critical stage regarding this indicator, even after years of field activity coordinated by UN development-related agencies.

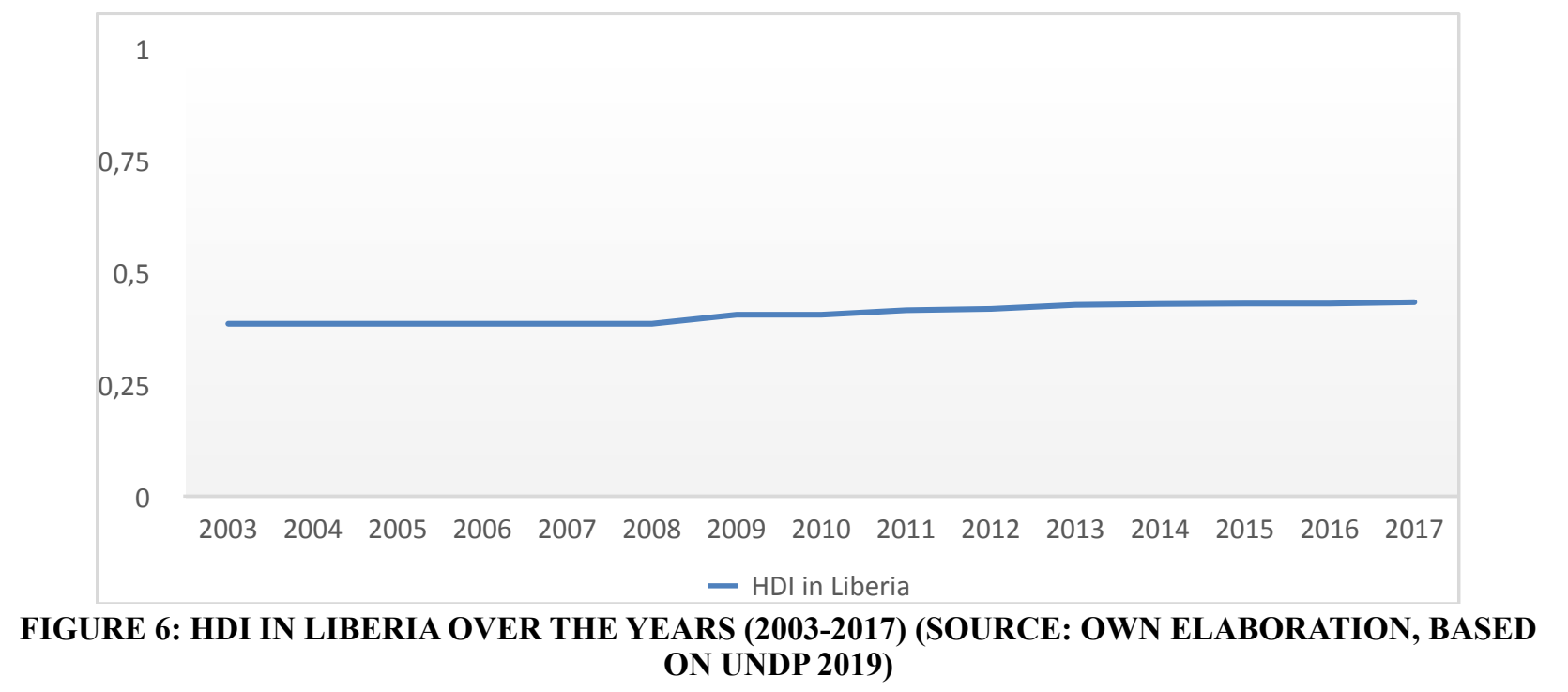

Generally, concerning the nexus between peace and development, the liberal trait adopted by the United Nations within UNMIL has indeed improved the state's performance on structural and direct economic issues - such as "Economic Decline" and the implementation of international standards of governance.
However, in crucial spheres the UN has been less efficient to address the root causes of the civil war in Liberia. Thus, indicators related to local dynamics evidenced that the big-P Peacebuilding policies deployed in Liberia have obtained little progress. 


\section{Conclusions}

As discussed throughout this paper, UN peacebuilding practice resembles the description of the big-P Peacebuilding approach. The organization focuses on the state level by promoting far-reaching institutional reforms to restore state authority and also to provide appropriate infrastructure for governments. This peacebuilding approach has also incorporated policies towards the promotion of economic development through a liberal perspective. Indeed, in the Liberian case, as discussed above, there is a direct nexus between peace, democracy and development that influenced the activities carried out by UNMIL and the UN system. Besides, even when the organization opened the path for inclusion of local people through the QIPs, projects approved are connected with the goals and tasks assigned in the mandate of the peace operation. Thus, this strengthens the argument of critical scholars that individuals are often constrained by the interests of international donors.

Indeed, the last section has evidenced several limitations of this approach in tackling the root causes of intrastate wars. For example, while investments were quite effective to address issues such as group grievance and reform of the security sector, the same cannot be said for the failed attempt to fragment local elites. This leads us to infer that the focus on economic development and democratic inclusion alone is not enough to bring about a horizontal transformation inasmuch policies tend to maintain and reinforce existing power structures and economic elites. In this case, it would take a more radical approach regarding income redistribution and economic and social inclusion to bring about more favorable results. In short, the logic of minimal state and implementation of liberal governance has not been sufficient to address inequality and local issues such as food insecurity.

Reforms addressed to restore state capacity bestowed some improvement during the intervention, such as those deployed to build capacity in the sectors of public services, human rights and rule of law. However, the same cannot be stated when one takes into account state legitimacy. In this regard, we consider that the process of democratization only dispenses good results when it bears in mind the local cultural imaginary. In the case of Liberia, the country has had little time to adapt and internalize democratic values. This has caused sporadic electoral violence which threatens the democratic process. In the future, this issue could be settled with a greater concern in adopting democratic structures that meet the demands of the local people.

Conclusively, even in one of the best "success case", UN peacebuilding shows flaws in addressing critical issues at the societal level, thus evidencing the limits of the liberal approach focused on the nexus between peace, democracy and development. To evidence this limitation, we have consciously decided to measure the effectiveness of the UN big-P Peacebuilding strategy in Liberia considering their very own parameters and goals. Through those, we sought to demonstrate that, even when the measurement resorts to indicators associated with the liberal project, it is possible to identify the UN's inability to bring about a significant transformation on certain topics of its own post-conflict agenda. This inability reinforces the argument that UN practitioners have to rethink the way peacebuilding is deployed to deal with post-warfare issues. New possibilities for change have appeared in the past years within a vibrant scholarship on participatory approaches to measure the effectiveness of peacebuilding policies to rebuild war-torn societies. As we have argued 
above, these bottom-up approaches to measurement have often evidenced a paradox in which UN goals for the post-conflict peacebuilding phase frequently do not match the state's everyday demands for peace. In this sense, new critiques to the international-led peacebuilding project could be further identified whenever ordinary people share their particular views regarding the work UN peacebuilders carry out on the ground.

\section{Bibliographical References}

Autesserre, Séverine (2010) The Trouble with the Congo: Local Violence and the Failure of International Peacebuilding, New York: Cambridge University Press.

Autesserre, Séverine (2014) Peaceland: Conflict Resolution and the Everyday Politics of International Intervention, New York: Cambridge University Press.

Autesserre, Séverine (2017) International Peacebuilding and Local Success: Assumptions and Effectiveness, International Studies Review, vol. 19, pp. 114-132.

Blanco, Ramon (2015) The UN peacebuilding process: an analysis of its shortcomings in Timor-Leste, Revista Brasileira de Política Internacional, vol. 58, nº 1, pp. 42-62.

Campbell, Susanna; Peterson, Jenny H. (2013) Statebuilding. In Mac Ginty, Roger (Ed.). Routledge Handbook of Peacebuilding, London: Routledge.

Chandler, David (2010) The uncritical critique of "liberal peace", Review of International Studies, vol. 36, pp. 137-15.

CPA (2003) Comprehensive Peace Agreement between the Government of Liberia and the Liberians United for Reconciliation and Democracy (Lurd) and the Movement for Democracy in Liberia (Model) and Political Parties. Accra, Ghana, August 18.

De Coning, Cedric (2013) Understanding Peacebuilding as Essentially Local, Stability, vol. 2, $n^{\text {o }} 1$, pp 1-6.

Derouen Jr, Karl (2015) An Introduction to Civil Wars, Thousand Oaks: CQ Press.

DPKO; DFS (2017) Quick Impact Projects (QIPs). United Nations, New York, October 2017. [Online]. https://unmil.unmissions.org/sites/default/files/new_dpko_qip_policy.pdf [Accessed 21 October 2018].

FAOSTAT (2019) Liberia, FAO. [Online] Rome, September 2019. http://www.fao.org/faostat/ en/\#country/123 [Accessed 1 September 2019].

FFP (2017) Fragile States Index and Cast Framework Methodology. [Online]. Washington D.C., FFP. http://fundforpeace.org/fsi/indicators/ [Accessed 15 May 2018].

FFP (2019) Fragile States Index - Country Dashboard: Liberia. [Online]. Washington D.C., FFP. http://fundforpeace.org/fsi/country-data/ [Accessed 15 May 2018]

Firchow, Pamina (2018) Reclaiming Everyday Peace: Local Voices in Measurement and Evaluation After War, Cambridge: Cambridge University Press.

Firchow, Pamina; Anastasiou, Harry (2016) Peacebuilding in Theory and Practice. In Firchow, Pamina; Anastasiou, Harry (Eds.) Practical Approaches to Peacebuilding: Putting Theory to Work, Boulder and London: Lynne Rienner Publishers. 
Firchow, Pamina; Mac Ginty, Roger (2017) Measuring Peace: Comparability, Commensurability, and Complementarity Using Bottom-Up Indicators, International Studies Review, vol. 19, pp. 6-27.

Foster, Dulce et al (2009) A House with Two Rooms: Final Report of the Truth and Reconciliation Commission of Liberia Diaspora Project, The Advocates for Human Rights, Saint Paul: DRI Press.

Galtung, Johan (1969) Violence, Peace, and Peace Research, Journal of Peace Research, vol. 6, no 3, pp. 167-191.

Galtung, Johan (1990) Cultural Violence, Journal of Peace Research, vol. 27, $\mathrm{n}^{\mathrm{o}}$ 3, pp. 291-305.

Gomes, Aureo (2013) Da Paz Liberal à Virada Local: Avaliando a Literatura Crítica Sobre Peacebuilding, Monções, vol. 2, no 3, pp. 46-76.

Harris, David (2012) Civil War and Democracy in West Africa: Conflict Resolution, Elections and Justice in Sierra Leone and Liberia, London \& New York: I.B. Tauris.

Höglund, Kristine; Kovacs, Mimmi S. (2010) Beyond the absence of war: the diversity of peace in post-settlement societies, Review of International Studies, vol. 36, pp. 367-390.

Höglund, Kristine; Kovacs, Mimmi S; Thyiagaraja, Waradas (2016) The Peace Triangle: Capturing Peace After Military Victory in Sri Lanka, In Firchow, Pamina; Anastasiou, Harry (Eds.) Practical Approaches to Peacebuilding: Putting Theory to Work, Boulder and London: Lynne Rienner Publishers.

Kang, Seonjou (2006) Post-conflict economic development and sustaining the peace, In Mason, Thomas D.; Meernick, James. Conflict Prevention and Peacebuilding in Post-War Societies: Sustaining the Peace, Abingdon and New York: Routledge.

Kappler, Stefanie (2014) Local Agency and Peacebuilding: EU and International Engagement in Bosnia-Herzegovina, Cyprus and South Africa, London: Palgrave Macmillan.

Krause, Keith; Jütersonke, Oliver (2005) Peace, Security and Development in Post-Conflict Environments, Security Dialogue, vol. 36, nº 4, pp. 447-462.

Layne, Christopher (1994) Kant or Can't: The Myth of Democratic Peace, International Security, vol. 19, no 2, pp. 5-49.

Lederach, John P (1997) Building Peace: Sustainable Reconciliation in Divided Societies, Washington D.C.: United States Institute of Peace Press.

Leonardsson, Hanna; Rudd, Gustav (2015) The "local turn" in peacebuilding: a literature review of effective and emancipatory local peacebuilding, Third World Quarterly, vol. 36, $\mathrm{n}^{\mathrm{o}}$ 5, pp. 825-839.

Liberia (2007) Interim Poverty Reduction Strategy: Breaking the Past from Conflict to Development, IMF Country Report No. 07/60, Washington D.C.

Mac Ginty, Roger (2006) No War, No Peace: The Rejuvenation of Stalled Peace Process and Peace Accords, Basingstoke: Palgrave Macmillan.

Mac Ginty, Roger (2010) Hybrid Peace: The Interaction Between Top-Down and Bottom-Up Peace, Security Dialogue, vol. 41, nº 4, pp. 391-412.

Mac Ginty, Roger (2011) International Peacebuilding and Local Resistance: Hybrid Forms of Peace, London: Palgrave Macmillan. 
Mac Ginty, Roger (2018) Governance and Negotiations: Whose quality standards? In Joshi, Madhav; Wallensteen, Peter (Eds.) Understanding Quality Peace: Peacebuilding after Civil War, London and New York: Routledge.

Mac Ginty, Roger; Richmond, Oliver P (2013) The Local Turn in Peace Building: a critical agenda for peace, Third World Quarterly, vol. 34, n 5, pp. 763-783.

Mac Ginty, Roger; Joshi, Madhav; Lee, SungYong (2019) Liberal Peace Implementation and the Durability of Post-war Peace, International Peacekeeping, vol. 26, nº 4, pp. 457-486.

Mac Ginty, Roger; Firchow, Pamina (2016) Top-down and bottom-up narratives of peace and conflict, Politics, vol. 36, no 3, pp. 1-16.

Millar, Gearoid (2014) An Ethnographic Approach to Peacebuilding: Understanding Local Experiences in Transitional States, London and New York: Routledge.

MSF (2016) Ebola na Guiné, na Libéria e em Serra Leoa. [Online] Geneva, Switzerland. [Online]. https://www.msf.org.br/noticias/ebola-na-guine-na-liberia-e-em-serra-leoa [Accessed 15 June 2020].

Newman, Edward (2013) The International Architecture of Peacebuilding, In Mac Ginty, Roger (Ed.) Routledge Handbook of Peacebuilding, Abingdon and New York: Routledge.

Nilsson, Desiree (2009) "Crafting a Secure Peace: Evaluating Liberia's Comprehensive Peace Agreement 2003”. Uppsala: Department of Peace and Conflict Research.

Paffenholz, Thania (2009) "Understanding the conflict-development nexus and the contribution of development cooperation to peacebuilding". In Sandole, Dennis et al. Handbook of Conflict Analysis and Resolution, Abingdon: Routledge.

Paffenholz, Thania (2015) Unpacking the local turn in peacebuilding: a critical assessment towards an agenda for future research, Third World Quarterly, vol. 36, nº 5, pp. 857-874.

Paris, Roland (1997) Peacebuilding and the Limits of Liberal Internationalism, International Security, vol. 22, no 2, pp. 54-89.

Pugh, Michael (2009) Toward Life Welfare, In Newman, Edward, Paris, Roland; Richmond, Oliver P. (Eds.) New Perspectives on Liberal Peacebuilding, Tokyo: United Nations University Press.

Pugh, Michael (2013) The problem-solving and critical paradigms, In Mac Ginty, Roger (Ed.) Routledge Handbook of Peacebuilding, London: Routledge.

Richmond, Oliver P. (2010) Para Além da Paz Liberal? Respostas ao "Retrocesso". Contexto Internacional, vol. 32, nº 2, pp. 297-332.

Richmond, Oliver P. (2014) Failed Statebuilding: Intervention and the Dynamics of Peace Formation, New Haven and London: Yale University Press.

Ryan, Stephen (2013) The Evolution of Peacebuilding, In Mac Ginty, Roger (Ed.) Routledge Handbook of Peacebuilding, Abingdon and New York: Routledge.

Sayle, Timothy et al (2009) Liberia: Assessing the Conditions for Liberal Democracy in a Postconflict State, Creating an International Network of Democracy Builders, The Center for the Study of Democracy, School of Policy Studies. Ontario: Queen's University.

Schulenburg, Michal (2017) On Building Peace: Rescuing the Nation-State and Saving the United Nations, Amsterdam: Amsterdam University Press. 
Smith, Edward (2015) The traditional routes to security: Realism and Liberalism, In Hough, Peter et al (Eds.) International Security Studies: Theory and Practice, Abingdon and New York: Routledge.

Souza, Matheus (2018) "A Atuação das Nações Unidas em Contextos Pós-conflito: Uma Análise do Processo de Captura da Paz na Libéria (2003-2018)". [Online]. Master's thesis, Pontificia Universidade Católica de Minas Gerais, Belo Horizonte. http:// www.biblioteca.pucminas.br/teses/RelInternac_SouzaMA_1.pdf [Accessed 15 June 2020].

Stern, Maria; Öjendal, Joakim (2013) Exploring the Security-Development Nexus, In Ramses, Amer; Swain, Ashok; Öjendal, Joakim (Eds.) The Security-Development Nexus: Peace, Conflict and Development, London and New York: Anthem Press.

The Carter Center (2017) National Elections in Liberia, Fall 2017 - Final Report, The Carter Center, Atlanta, GA.

Tom, Patrick (2017) Liberal Peace and Post-Conflict Peacebuilding in Africa, London: Palgrave Macmillan.

Tschirgi, Necla (2015) Rebuilding War-Torn Societies: A Critical Review of International Approaches, In Crocker, Chester; Hampson, Fen Osler; Aall, Pamela (Eds.) Managing Conflict in a World Adrift, Washington D.C.: United States Institute for Peace Press.

UN (2003a) Letter dated 29 July 2003 from the Secretary-General addressed to the President of the Security Council, S/2003/769. [Online]. United Nations, New York, Jul. 29. https:// undocs.org/S/2003/769 [Accessed 15 September 2018].

UN (2003b) Report of the Secretary-General to the Security Council on Liberia, S/2003/875. [Online]. United Nations, New York, Sep. 11. https:/www.securitycouncilreport.org/atf/cf/ \%7b65BFCF9B-6D27-4E9C-8CD3-CF6E4FF96FF9\%7d/Liberia\%20S2003\%20875.pdf [Accessed 15 September 2018]

UN (2003c) Resolution 1509 (2003), S/RES/1497 (2003). [Online]. United Nations, New York. https://undocs.org/S/RES/1497(2003) [Accessed 15 September 2018]

UN (2003d) Budget for the United Nations Mission in Liberia for the period from 1 August 2003 to 30 June 2004: Report of the Secretary-General, A/58/539. [Online]. United Nations, New York. http://www.un.org/en/ga/search/view_doc.asp?symbol=A/58/539 [Accessed 15 September 2018].

UN (2004a) Budget for the United Nations Mission in Liberia for the period from 1 August 2004 to 30 June 2005: Report of the Secretary-General, A/58/744. [Online]. United Nations, New York. http://www.un.org/en/ga/search/view_doc.asp?symbol=A/58/744 [Accessed 15 September 2018].

UN (2004b) Budget for the United Nations Mission in Liberia for the period from 1 July 2005 to 30 June 2006: Report of the Secretary-General, A/59/630. [Online]. United Nations, New York. http://www.un.org/en/ga/search/view_doc.asp?symbol=A/59/630 [Accessed 15 September 2018].

UN (2006) Budget for the United Nations Mission in Liberia for the period from 1 July 2006 to 30 June 2007: Report of the Secretary-General, A/60/653. [Online]. United Nations, New York. http://www.un.org/en/ga/search/view_doc.asp?symbol=A/60/653. [Accessed 15 September 2018].

UN (2007) Budget for the United Nations Mission in Liberia for the period from 1 July 2007 to 30 June 2008: Report of the Secretary-General, A/61/783. [Online]. United Nations, New York. http://www.un.org/en/ga/search/view_doc.asp?symbol=A/61/783 [Accessed 15 September 2018]. 
UN (2008) Budget for the United Nations Mission in Liberia for the period from 1 July 2008 to 30 June 2009: Report of the Secretary-General,A/63/296. [Online]. United Nations, New York. https://www.un.org/en/ga/search/view_doc.asp?symbol=A/RES/63/296 [Accessed 15 September 2018].

UN (2009) Budget for the United Nations Mission in Liberia for the period from 1 July 2009 to 30 June 2010: Report of the Secretary-General, A/63/734. [Online]. United Nations, New York. http://www.un.org/en/ga/search/view_doc.asp?symbol=A/63/734 [Accessed 15 September 2018].

UN (2010) Budget for the United Nations Mission in Liberia for the period from 1 July 2010 to 30 June 2011: Report of the Secretary-General,A/64/647. [Online]. United Nations, New York. http://www.un.org/en/ga/search/view_doc.asp?symbol=A/64/647 [Accessed 15 September 2018].

UN (2011) Budget for the United Nations Mission in Liberia for the period from 1 July 2011 to 30 June 2012: Report of the Secretary-General,A/65/727. [Online]. United Nations, New York. http://www.un.org/en/ga/search/view_doc.asp?symbol=A/65/727 [Accessed 15 September 2018].

UN (2012) Budget for the United Nations Mission in Liberia for the period from 1 July 2012 to 30 June 2013: Report of the Secretary-General,A/66/691. [Online]. United Nations, New York. http://www.un.org/en/ga/search/view_doc.asp?symbol=A/66/691 [Accessed 15 September 2018].

UN (2013) Budget for the United Nations Mission in Liberia for the period from 1 July 2013 to 30 June 2014: Report of the Secretary-General,A/RES/68/291. [Online]. United Nations, New York. http://www.un.org/en/ga/search/view_doc.asp?symbol=A/RES/68/29 [Accessed 15 September 2018].

UN (2014) Budget for the United Nations Mission in Liberia for the period from 1 July 2014 to 30 June 2015: Report of the Secretary-General, A/68/761. [Online]. United Nations, New York. https://www.un.org/en/ga/search/view_doc.asp?symbol=A/RES/70/278 [Accessed 15 September 2018].

UN (2015) Budget for the United Nations Mission in Liberia for the period from 1 July 2015 to 30 June 2016: Report of the Secretary-General,A/70/278. [Online]. United Nations, New York. http://www.un.org/en/ga/search/view_doc.asp?symbol=A/68/761 [Accessed 15 September 2018].

UN (2016) Budget for the United Nations Mission in Liberia for the period from 1 July 2016 to 30 June 2017: Report of the Secretary-General, A/RES/71/304. [Online]. United Nations, New York. https://www.un.org/en/ga/search/view_doc.asp?symbol=A/RES/71/304 [Accessed 15 September 2018].

UN (2017) Budget for the United Nations Mission in Liberia for the period from 1 July 2017 to 30 June 2018: Report of the Secretary-General,A/71/847, United Nations, New York.

UNDAF Liberia (2003) Liberia: United Nations Development Assistance Framework (a modified UNDAF) 2003 - 2005. United Nations: New York.

UNDAF Liberia (2007) United Nations Development Assistance Framework for Liberia 2008-2012: Consolidating Peace and National Recovery for Sustainable Development [Online]. New York: United Nations. https://www.unicef.org/about/execboard/files/UNDAFLiberia-2008-2012.pdf [Accessed 15 September 2018].

UNDAF Liberia (2012) One Programme: UN Development Assistance Framework (UNDAF 2013-2017). [Online]. New York: United Nations. https://www.unicef.org/liberia/ UNDAF_2013-2017.pdf [Accessed 15 September 2018]. 
UNDP (2019) Liberia - Human Development Indicators, United Nations Development Programme. [Online]. New York, Human Development Reports. Accessed September 2019, Accessed August 2018 http://hdr.undp.org/en/countries/profiles/LBR\# [Accessed 15 September 2018].

UNMIL (2016a) Quick Impact Projects 2003-2016. [Online]. UNMIL, Monrovia. https:// unmil.unmissions.org/sites/default/files/quick_impact_projects-_2003_-2016web.pdf [Accessed 15 September 2018].

UNMIL (2016b) Comprehensive summary of Quick Impact Project (QIPs) of 2016/2017 Financial Year. [Online]. UNMIL, Monrovia. https://unmil.unmissions.org/sites/default/files/ qips_implemented_in_the_2016-2017.pdf[Accessed 15 September 2018].

UNMIL (2017) UNMIL Quick Impact Project Unit. [Online]. UNMIL, Monrovia.

https://unmil.unmissions.org/sites/default/files/2017-2018__summary_of_projects_formally_closed-21_march_2018.pdf[Accessed 15 September 2018].

Vogel, Birte (2016) Civil Society Capture: Top-Down Interventions from Below?, Journal of Intervention and Statebuilding, vol. 10, $\mathrm{n}^{\mathrm{o}} 4$, pp. 1-18.

Wallensteen, Peter (2007) Understanding Conflict Resolution: War, Peace and the Global System, London: Sage Publications.

Waugh, Colin (2011) Charles Taylor and Liberia: Ambition and Atrocity in Africa's Lone Star State, London \& New York: Zed Books.

World Bank (2019) DataBank - Worldwide Governance Indicators. [Online]. Washington D.C, World Bank. https://databank.worldbank.org/source/worldwide-governance-indicators\#. [Accessed 15 September 2019].

\author{
PROCESO EDITORIAL • EDITORIAL PROCESS INFO \\ Recibido: 13/12/2019 Aceptado: 20/06/2020
}

\title{
CÓMO CITAR ESTE ARTÍCULO • HOW TO CITE THIS PAPER
}

Souza, Matheus de Abreu Costa; Mendes, Cristiano Garcia (2020) Building Peace Through the Nexus between Security, Democracy and Development: A Critical Assessment of the United Nations Mission in Liberia. Revista de Paz y Conflictos, Vol.13 (1), 73-98.

\section{SOBRE LOS AUTORES > ABOUT THE AUTHORS}

Matheus Souza is a PhD Student at the Institute of International Relations (IRI) from the Pontifical Catholic University of Rio de Janeiro (PUC-Rio). He holds a Master's (2018) and Bachelor's (2016) degrees in International Relations (PUC Minas). His research interests are on critical peace studies, IR critical theories, peacebuilding, everyday peace, UN peace operations and intrastate warfare.

Cristiano Mendes is a Professor of International Relations at the Department of International Relations, PUC Minas, Brazil. He holds a PhD in International Relations from University of Brasília (UnB) and a Master's in Political Science from the Federal University of Minas Gerais, Brazil. Professor Mendes is the author of articles and book chapters about terrorism, failed states and private military and security companies. He was a visiting professor at the University of Sydney, Australia (2011), and a visiting researcher at the University of Coimbra, Portugal (2014). Professor Mendes' area of research focuses on security studies and post-positivist theories of International Relations. 